\title{
INTERINDIVIDUAL AND INTRAINDIVIDUAL PHARMACOKINETIC VARIABILITY OF TACROLIMUS WITHIN THE FIRST YEAR AFTER RENAL TRANSPLANTATION: EFFECT OF CYP3A5 GENE POLYMORPHISM
}

\author{
Nikola Stefanović1, Radmila Veličković-Radovanović1,2, Aleksandra Catić-Djordjević1, \\ Ivana Damnjanović ${ }^{1}$, Katarina Dinićs , Branka Mitićc,4, Tatjana Jevtović-Stoimenov ${ }^{5}$, \\ Jelena Bašićs, Milena Despotovićs, Tatjana Cvetković2,
}

\begin{abstract}
The aim of this study was to evaluate potential influence of cytochrome P450 3A5 (CYP3A5) 6986A>G gene polymorphisms on inter- and intravariability (IPV) in tacrolimus (Tac) exposure within the first year after renal transplantation. Secondary, we aimed to analyze the change in distribution of patients regarding IPV between early ( $<6$ months) and late posttransplant period (>6 months). The study enrolled 91 renal transplant recipients, who were on Tac-based immunosuppressive protocol. Dose-adjusted concentration (CO/D) of Tac was used as a measure of Tac exposure, while coefficient of variation $(\mathrm{CV} \%)$ and mean absolute deviation (MAD\%) of CO/D as IPV parameters. Individuals carrying CYP3A5*1/*3 genotype had lower CO/D than CYP3A5*3/*3 carriers within the entire observation period $(p<0.01)$. The study reported higher IPV in a period of 1-6 months compared to a period of 7-12 months posttransplant, for CV\% and MAD\% $(p<0.05)$. The results showed that there was no difference in IPV regarding CYP3A5 genotype. Considering CV\%, 32\% and $24 \%$ of the patients had high IPV (above $30 \%$ ) in the first and second half of the first post-transplant year, respectively. Analyzing the $\mathrm{MAD} \%, 13 \%$ and $7 \%$ of the patients had high variability of Tac exposure in the first and second half of the first year, respectively. This study confirms that the CYP3A5 gene polymorphism contributes to the interindividual, but not in intraindividual, variability in Tac exposure within the first post-transplant year.
\end{abstract}

Acta Medica Medianae 2019;58(1):93-101.

Key words: CYP3A5, renal transplantation, tacrolimus, interindividual pharmacokinetic variability, intraindividual pharmacokinetic variability

\footnotetext{
${ }^{1}$ University of Niš, Faculty of Medicine, Department of Pharmacy, Niš, Serbia

${ }^{2}$ Clinic of Nephrology, Clinical Centre Niš, Niš, Serbia

${ }^{3}$ University of Niš, Faculty of Medicine, Niš, Serbia

${ }^{4}$ University of Niš, Faculty of Medicine, Department of Internal

Medicine, Niš, Serbia

${ }^{5}$ University of Niš, Faculty of Medicine, Department of

Biochemistry, Niš, Serbia
}

Contact: Nikola Stefanović

Blvd. Dr. Zoran Djindjić 81, 18000 Niš, Serbia

E-mail: nikola.stefanovic@medfak.ni.ac.rs

\section{Introduction}

Tacrolimus (Tac) is widely used as part of the most immunosuppressive protocols after renal transplantation $(\mathrm{Tx})$. Its clinical use is complicated by large interindividual pharmacokinetic variability and chronic nephrotoxicity, which may lead to graft loss in the late post-transplant period (1). The attempts to replace Tac with other, equally effective but less toxic immunosuppressive drugs, have had limited success. Therefore, Tac will remain the first choice immunosuppressive agent for the next decade or so, and optimization of Tac-based immunosuppressive therapy is of utmost importance (2). Hence, therapeutic drug monitoring of Tac is a necessary tool with a view to reduce the toxicity and improve efficacy. Still, there are patients who will experience adverse effects or lack in efficacy with the Tac concentration in the optimal range, which suggests that additional investigation of the factors that may contribute to these effects is needed $(3,4)$. It is showed that genetics was one of the main determinants, along with demographic factors and drug-drug interactions that affects interindividual variability in Tac pharmacokinetics $(4,5)$. Gene polymorphism (6986 A $>$ G) present within cytochrome P450 3A5 (CYP3A5) is assumed to be the major determinant of the Tac pharmacokinetic variability. The presence of $A$ allele at the polymorphic site in the CYP3A5 gene suggests that an individual has a functionally active enzyme (expresser) and carries one of the two genotypes 
(CYP3A5*1/*1 or CYP3A5*1/*3). Non - expressers carry CYP3A5*3/*3 genotype and do not have active enzyme $(4,6)$. The role of CYP3A5 gene polymorphism is well documented for the early post-transplant period (up to 3 months post-transplant), while its role in the late post-transplant period (after 6 months post-transplant) is not elucidated in its entirety $(4,7,8)$.

Besides interpatient pharmacokinetic variability, tacrolimus exerts considerable intraindividual or intrapatient variability (IPV) in its pharmacokinetics. Intrapatient variability represents fluctuation in Tac concentrations within an individual patient over a certain period of time during which the Tac dose is unchanged (2). Patients with highly fluctuated Tac concentrations are at risk either for underexposure and rejection or to overexposure and Tac toxicity. Recently, it is demonstrated that high IPV in Tac exposure may be a predictor for long-term adverse outcome after Tx (9). Still, whether CYP3A5 genotype also affects Tac IPV or not, is not completely understood.

The aim of this study was to evaluate the potential influence of CYP3A5 (6986A > G) gene polymorphisms on inter- and intraindividual variability in Tac exposure within the first year after Tx. Secondary, we aimed to analyze the change in the distribution of patients regarding Tac IPV between early (< 6 months) and late post-transplant period ( $>6$ months).

\section{Patients and methods}

\section{Patients}

The pharmacokinetic-pharmacogenetic study was conducted at the Clinic of Nephrology, Clinical Centre Niš, Serbia and at the Research Centre for Biomedicine, Faculty of Medicine, University of Niš, Serbia between 2008-2016. The genotyping analysis included 91 patients who had transplantation surgery at Clinical Centre Niš and were monitored at the Clinic of Nephrology during the study period. The study involved a period from 1 up to 12 months after Tx, with 1564 routine controls at the Clinic and in 1515 cases Tac concentration was measured, which was valid for the analysis. Of all patients enrolled into pharmacokinetic study, 56 were men and 35 were women, mean age $40.57 \pm 10.74$ at the beginning of the study, 66 out of 91 patients had living donor transplantation and 25 out of 91 got their organ from deceased donors. Besides standard immunosuppressive therapy, patients also received antihypertensive drugs (beta-blockers, bisoprolol, metoprolol or carvedilol and calcium channel blockers, amlodipine in monotherapy, as well as in the combination) and omeprazole, pantoprazole or ranitidine as gastroprotective. The study was approved by the Ethics Committee of Medical Faculty Nis and fully informed written consent was obtained from each patient (0110204-13 from 2012. and 12-2307-2/5 from 2016.).

\section{Immunosupressive protocol}

All patients started with a quaternary immunosuppressive protocol that besides Tac included intravenous methylprednisolone (MP), with an initial dose of $0.5 \mathrm{~g} /$ day and 2 or 3 days later it was switched to prednisone (Pre), initial dose of $1 \mathrm{mg} / \mathrm{kg} /$ day, mycophenolate mofetil (MMF), $2 \mathrm{~g} /$ day or mycophenolic acid (MPA), $1440 \mathrm{mg} /$ day orally and $20 \mathrm{mg}$ monoclonal antibody basiliximab (Bas) which was administered at the first and the fourth day after transplantation. The first oral Tac dose was administered on day 5 post-transplant at $8.00 \mathrm{hr}$ before breakfast 0.05 $\mathrm{mg} / \mathrm{kg}$. Furthermore, Tac was administered twice daily (08.00 h and $20.00 \mathrm{~h}$ ) for twice-daily Tac formulation or once daily (08.00h) for once-daily Tac formulation and the dose was adjusted according to the trough concentration of a drug in the blood, in order to maintain drug trough concen-tration (CO) in the appropriate range (5 - $15 \mathrm{ng} / \mathrm{mL}$ ). Tacrolimus blood trough concentration was measured by immunoassay method according to the manufacturer's instructions (Architect, Abbott, Ab-bott Park, IL, USA).

\section{Pharmacokinetic data}

For the purpose of the analysis we used a daily dose, trough concentration (CO) and dose-adjusted concentration (CO/D) of Tac from routine controls at the Clinic (1515) during the first year after Tx. As not all patients received a constant drug dose in the observed period, we calculated CO/D ( $\mathrm{ng} \mathrm{mL}^{-1}$ $\left./ \mathrm{mg} \mathrm{day}^{-1}\right)$ of Tac as CO $(\mathrm{ng} / \mathrm{mL})$ divided by the corresponding dose of Tac (mg/day).

\section{Intrapatient variability}

The IPV in Tac exposure were calculated in a period of 1-6 months, in a period of 7-12 months and in a period of 1-12 months post-transplant. In the conducted study we used two parameters of Tac IPV: coefficient of variation (CV\%), calculated as the mean of CO/D divided by standard deviation of CO/D for the concrete observation period and mean absolute deviation (MAD\%), calculated as:

$$
M A D \%=\frac{1}{N} \sum_{n=1}^{N} \frac{a b s\left(x_{n}-\bar{x}\right)}{\bar{x}} \times 100
$$

where $\bar{X}$ is the mean CO/D of all available samples in the period of 1-12 months after Tx; $X_{n}$ is an individual value of CO/D measured in the period mentioned, and $\mathrm{N}$ is the number of all available values for an individual patient.

\section{Biochemical data}

A fasting blood sample was taken from each 
patient during routine control at the Clinic. Of the whole blood sample, $200 \mu \mathrm{L}$ was taken for DNA isolation. DNA was extracted from the whole blood with EDTA as an anticoagulant using Genomic DNA Purification Kit (Fermentas, Thermo Scientific, Lithuania) according to the manufacturer's instructions. Serum level of albumin (ALB), urea (URE), creatinine (CRE) and the activities of aspartate aminotransfe- rase (AST) and alanine aminotransferase (ALT) were measured by standard methods in the Biochemical laboratory at Clinic of Nephrology. Analyses were performed on the Automated random access clinical chemistry analyzer (ERBA XL - 600, ERBA Diagnostics Mannheim GmbH, Mannheim, Germany). Glomerular filtration rate was estimated (eGFR) by MDRD formula for creatinine clearance.

Table 1. Clinical and demographic characteristics of the renal transplant recipients in different post-transplant periods

\begin{tabular}{|c|c|c|c|}
\hline PARAMETERS & $\begin{array}{c}\text { Period 1-6 months } \\
\text { after Tx } \\
\end{array}$ & $\begin{array}{c}\text { Period 7-12 months } \\
\text { after Tx }\end{array}$ & $\begin{array}{c}\text { Period 1-12 months } \\
\text { after Tx } \\
\end{array}$ \\
\hline $\begin{array}{c}\text { Number of check-ups at } \\
\text { the Clinic }\end{array}$ & 877 & 638 & 1515 \\
\hline Check-up per patient & $\begin{array}{c}8.91 \pm 4.42 \\
8(6-10) \\
\end{array}$ & $\begin{array}{c}8.69 \pm 2.08 \\
8(7-10) \\
\end{array}$ & $\begin{array}{c}16.65 \pm 6.12 \\
16(13-21)\end{array}$ \\
\hline Sex (male/ female) & \multicolumn{3}{|c|}{$56 / 35$} \\
\hline Age (years) & \multicolumn{3}{|c|}{$\begin{array}{c}40.57 \pm 10.74 \\
40(32-49)\end{array}$} \\
\hline $\begin{array}{c}\text { Donor type } \\
\text { (living/deceased) }\end{array}$ & \multicolumn{3}{|c|}{$66 / 25$} \\
\hline Body weight $(\mathrm{kg})$ & $\begin{array}{c}72.00 \pm 13.97 \\
70(64-80) \\
\end{array}$ & $\begin{array}{c}74.06 \pm 12.95 \\
72(66-80) \\
\end{array}$ & $\begin{array}{l}73.10 \pm 13.36 \\
71(65-80) \\
\end{array}$ \\
\hline CRE $(\mu \mathrm{mol} / \mathrm{L})$ & $\begin{array}{c}146.55 \pm 43.87 \\
139(116-177) \\
\end{array}$ & $\begin{array}{c}136.04 \pm 40.79 \\
130(111-149) \\
\end{array}$ & $\begin{array}{c}141.65 \pm 42.12 \\
135(113-163) \\
\end{array}$ \\
\hline eGFR $\left(\mathrm{mL} / \mathrm{min} / 1.73 \mathrm{~m}^{2}\right)$ & $\begin{array}{c}50.06 \pm 16.67 \\
49(38-58) \\
\end{array}$ & $\begin{array}{l}53.82 \pm 17.88 \\
53(42.50-61)\end{array}$ & $\begin{array}{c}51.74 \pm 17.07 \\
51(41-60) \\
\end{array}$ \\
\hline URE (mmol / L) & $\begin{array}{c}9.22 \pm 4.34 \\
9(7-11) \\
\end{array}$ & $\begin{array}{c}8.15 \pm 3.28 \\
8(6-10) \\
\end{array}$ & $\begin{array}{c}8.49 \pm 3.72 \\
8(6-10) \\
\end{array}$ \\
\hline ALB $(g / L)$ & $\begin{array}{c}40.31 \pm 4.15 \\
41(38-43)\end{array}$ & $\begin{array}{c}41.23 \pm 4.35 \\
41(39-44)\end{array}$ & $\begin{array}{c}40.42 \pm 4.28 \\
41(38-43)\end{array}$ \\
\hline $\operatorname{ALT}(U / L)$ & $\begin{array}{c}41.37 \pm 38.42 \\
28(20-44)\end{array}$ & $\begin{array}{l}38.44 \pm 32.08 \\
28(20-44.50)\end{array}$ & $\begin{array}{l}39.87 \pm 35.00 \\
28(20-45)\end{array}$ \\
\hline AST (U/L) & $\begin{array}{c}22.93 \pm 15.07 \\
20(16-25)\end{array}$ & $\begin{array}{l}22.93 \pm 15.07 \\
21(16.50-26)\end{array}$ & $\begin{array}{l}24.18 \pm 15.25 \\
20.50(16-26)\end{array}$ \\
\hline $\begin{array}{c}\text { OD/TD } \\
\text { Tac formulation }\end{array}$ & \multicolumn{3}{|c|}{$13 / 78$} \\
\hline Dose of Tac (mg/day) & $\begin{array}{c}6.81 \pm 3.76 \\
6.00(4.00-9.00) \\
\end{array}$ & $\begin{array}{c}4.66 \pm 2.77 \\
4.00(3.00-6.00) \\
\end{array}$ & $\begin{array}{c}5.71 \pm 3.49 \\
5.00(3.00-7.00) \\
\end{array}$ \\
\hline $\mathrm{CO}$ of Tac $(\mathrm{ng} / \mathrm{mL})$ & $\begin{array}{c}8.82 \pm 2.93 \\
8.00(7.00-10.00) \\
\end{array}$ & $\begin{array}{c}7.26 \pm 2.41 \\
7.00(6.00-9.00) \\
\end{array}$ & $\begin{array}{c}7.95 \pm 2.89 \\
8.00(6.00-10.00) \\
\end{array}$ \\
\hline $\begin{array}{c}\text { CO/D of Tac } \\
\left(\mathrm{ng} \mathrm{mL}^{-1} / \mathrm{mg} \mathrm{kg}^{-1} \mathrm{day}^{-1}\right)\end{array}$ & $\begin{array}{c}1.60 \pm 0.84 \\
1.47(0.97-2.03) \\
\end{array}$ & $\begin{array}{c}1.98 \pm 1.18 \\
1.67(1.20-2.40) \\
\end{array}$ & $\begin{array}{c}1.77 \pm 1.02 \\
1.55(1.08-2.15)\end{array}$ \\
\hline Dose of Pre (mg/day) & $\begin{array}{c}14.94 \pm 8.20 \\
10(10-20) \\
\end{array}$ & $\begin{array}{c}10.05 \pm 2.23 \\
10(10-10) \\
\end{array}$ & $\begin{array}{c}12.92 \pm 6.85 \\
10(10-12) \\
\end{array}$ \\
\hline $\mathrm{MPA}+\mathrm{Tac} / \mathrm{mTOR}+\mathrm{Tac}$ & \multicolumn{3}{|c|}{$84 / 7$} \\
\hline Dose of MPA (mg/day)* & $\begin{array}{c}1059.32 \pm 327.65 \\
1080(720-1440)\end{array}$ & $\begin{array}{c}1095.61 \pm 318.33 \\
1080(720-1440)\end{array}$ & $\begin{array}{c}1119.32 \pm 324.75 \\
1080(720-1440)\end{array}$ \\
\hline $\begin{array}{c}\text { CYP3A5 genotype } \\
(* 1 * 3 / * 3 * 3)\end{array}$ & \multicolumn{3}{|c|}{$13 / 78$} \\
\hline
\end{tabular}

Data are expressed as median (interquartile range) or number; eGFR was calculated by MDRD formula.

*MMF dose was calculated on MPA dose

Cre - serum creatinine level; Ure - serum urea level; Tac - tacrolimus; OD/TD - once daily/twice daily; Pre - prednisone; MMF - mycophenolate mofetil ; MPA - mycophenolic acid; CO - tacrolimus trough concentration; CO/D - tacrolimus dose adjusted trough concentration; CRE- serum creatinne; URE-serum urea; ALB-serum albumin; ALT- alanine aminotransferase; AST- aspartate aminotransferase; 


\section{Genotyping CYP3A5 polymorphism}

Genotyping was performed using TaqMan ${ }^{\circledR}$ Drug Metabolism Genotyping Assays for CYP3A5*3 (C_26201809_30) (Applied Biosystems, Carlsbad, CA, USA) on the Mx3005P Real-Time PCR System (Agilent Technologies), according to the manufacturer's instructions.

\section{Statistical analysis}

The characteristics of the study group were expressed as mean \pm standard deviation and median (interquartile range) or number. We used Student t-test for normally distributed data and Mann Whitney $U$ test for data that were not normally distributed to compare pharmacokinetic data and IPV between the groups of patients based on the CYP3A5 genotypes within same period after Tx. All analyses were performed with SPSS statistical analysis software, version 16.0 (SPSS, Chicago, IL, United States) at the significance level set at $p<0.05$.

\section{Results}

The characteristics of the study population are given in Table 1. Of all routine controls at the Clinic (1564), 1515 was valid for the pharmacokinetic study (C0 was measured), 877 took place in a period of 1-6 months, whereas 638 took place in a period of 7-12 months post-transplant. Considering routine control per patient, approximately every patient went to the Clinic 16 times during the first year, 8 times per six months.

Table 2. Dose, trough concentration and dose-adjusted trough concentration of Tac in relation to CYP3A5 genotype up to 12 months after transplantation

\begin{tabular}{|c|c|c|c|}
\hline Genotype & $\begin{array}{c}\text { Period 1-6 months } \\
\text { after Tx }\end{array}$ & $\begin{array}{c}\text { Period } 7-12 \text { months } \\
\text { after Tx }\end{array}$ & $\begin{array}{c}\text { Period } 1-12 \text { months } \\
\text { after Tx }\end{array}$ \\
\hline CYP3A5 & \multicolumn{3}{|c|}{ Dose (mg/day) } \\
\hline$* 1 / * 3$ & $\begin{array}{c}9.23 \pm 4.36 \\
9.00(6.00-11.00) \\
\end{array}$ & $\begin{array}{c}6.09 \pm 3.65 \\
6.00(4.00-8.00) \\
\end{array}$ & $\begin{array}{c}7.94 \pm 4.36 \\
8.00(5.00-10.00) \\
\end{array}$ \\
\hline$* 3 / * 3$ & $\begin{array}{c}6.19 \pm 3.22 \\
6.00(4.00-8.00)\end{array}$ & $\begin{array}{c}4.56 \pm 2.77 \\
4.00(3.00-6.00)\end{array}$ & $\begin{array}{c}5.50 \pm 2.77 \\
5.00(3.00-7.00)\end{array}$ \\
\hline P value & 0.000 & 0.000 & 0.000 \\
\hline CYP3A5 & \multicolumn{3}{|c|}{ CO $(\mathrm{ng} / \mathrm{mL})$} \\
\hline$* 1 / * 3$ & $\begin{array}{c}8.56 \pm 2.97 \\
9.00(7.00-11.00)\end{array}$ & $\begin{array}{c}6.89 \pm 2.78 \\
7.00(5.00-9.00)\end{array}$ & $\begin{array}{c}7.87 \pm 3.01 \\
8.00(6.00-10.00)\end{array}$ \\
\hline$* 3 / * 3$ & $\begin{array}{c}8.28 \pm 2.84 \\
8.00(6.00-10.00)\end{array}$ & $\begin{array}{c}7.18 \pm 2.38 \\
7.00(6.00-9.00)\end{array}$ & $\begin{array}{c}7.81 \pm 2.71 \\
8.00(6.00-9.00)\end{array}$ \\
\hline P value & 0.052 & 0.492 & 0.254 \\
\hline CYP3A5 & \multicolumn{3}{|c|}{$\begin{array}{c}\text { CO/D } \\
\left(\mathrm{ng} \mathrm{mL}^{-1} / \mathrm{mg} \mathrm{day}^{-1}\right)\end{array}$} \\
\hline$* 1 / * 3$ & $\begin{array}{c}1.03 \pm 0.40 \\
0.97(0.74-1.20)\end{array}$ & $\begin{array}{c}1.36 \pm 0.64 \\
1.18(0.90-1.68)\end{array}$ & $\begin{array}{c}1.17 \pm 0.54 \\
1.05(0.81-1.40)\end{array}$ \\
\hline$* 3 / * 3$ & $\begin{array}{c}1.62 \pm 0.86 \\
1.46(1.03-2.03)\end{array}$ & $\begin{array}{c}2.06 \pm 1.31 \\
1.67(1.21-2.47)\end{array}$ & $\begin{array}{c}1.81 \pm 1.09 \\
1.54(1.11-2.15)\end{array}$ \\
\hline P value & 0.000 & 0.000 & 0.000 \\
\hline
\end{tabular}

Data are expressed as mean \pm standrad deviation and median (interquratile range)

CO - tacrolimus trough concentration; CO/D - tacrolimus dose - adjusted trough concentration

Table 2. demonstrates comparison of Tac dose, $C O$ and CO/D among patients with different CYP3A5 genotype in the different periods after renal transplantation. Individuals carrying CYP3A5*1/*3 genotype had higher dose requirements and lower CO/D than CYP3A $5 * 3 / * 3$ carriers within the entire study period $(p=0.000)$. Alternatively, there was no difference in $\mathrm{CO}$ in relation to CYP3A5 genotype. 
Therefore, carriers of the active form of the CYP3A5 enzyme required higher daily dose of Tac to maintain optimal CO $(5-15 \mathrm{ng} / \mathrm{mL})$, not only in the early period ( $<6$ months post-transplant), but as well in the late period after Tx ( $>6$ months post-transplant).

Considering, Tac IPV, Graph 1. demonstrates higher IPV in a period of 1-6 months compared to a period of 7-12 months post-transplant, for both parameters, CV\% (27.10 \pm 11.23 vs. $23.62 \pm 10.07)$ and MAD\% $(20.97 \pm 9.13$ vs. $18.33 \pm 8.12)$. The IPV during the entire study period $(29.76 \pm 10.84$ for $\mathrm{CV} \%$ and $23.41 \pm 8.67$ for MAD\%) was higher than in the first and second six months (for MAD\%), but values were more close to the IPV in the first six months. Furthermore, there was no difference in CV\% between IPV in the first six months and IPV during the entire follow-up period, suggesting that early period significantly contributes to the 12 months post-transplant Tac IPV.
The obtained results showed that there was no difference in Tac IPV regarding CYP3A5 genotype (Graph 2).

Graph 3. shows the change in distribution of patients regarding Tac IPV between the observed periods after Tx. The results of the present research demonstrated that slightly above $50 \%$ of patients had medium IPV (between 15 and 30\%) in both observed periods. Considering CV\%, 32\% had high IPV and $12 \%$ of the patients had low IPV in the first six months post-transplant. Furthermore, in the second half of the first post-transplant year, fewer patients had high IPV (24\%), while $20 \%$ of the patients were low variable regarding Tac exposure. Analyzing the $M A D \%$, above $50 \%$ of renal transplant recipients had medium IPV, while $13 \%$ in the first and $7 \%$ in second half of the first year had high variability.

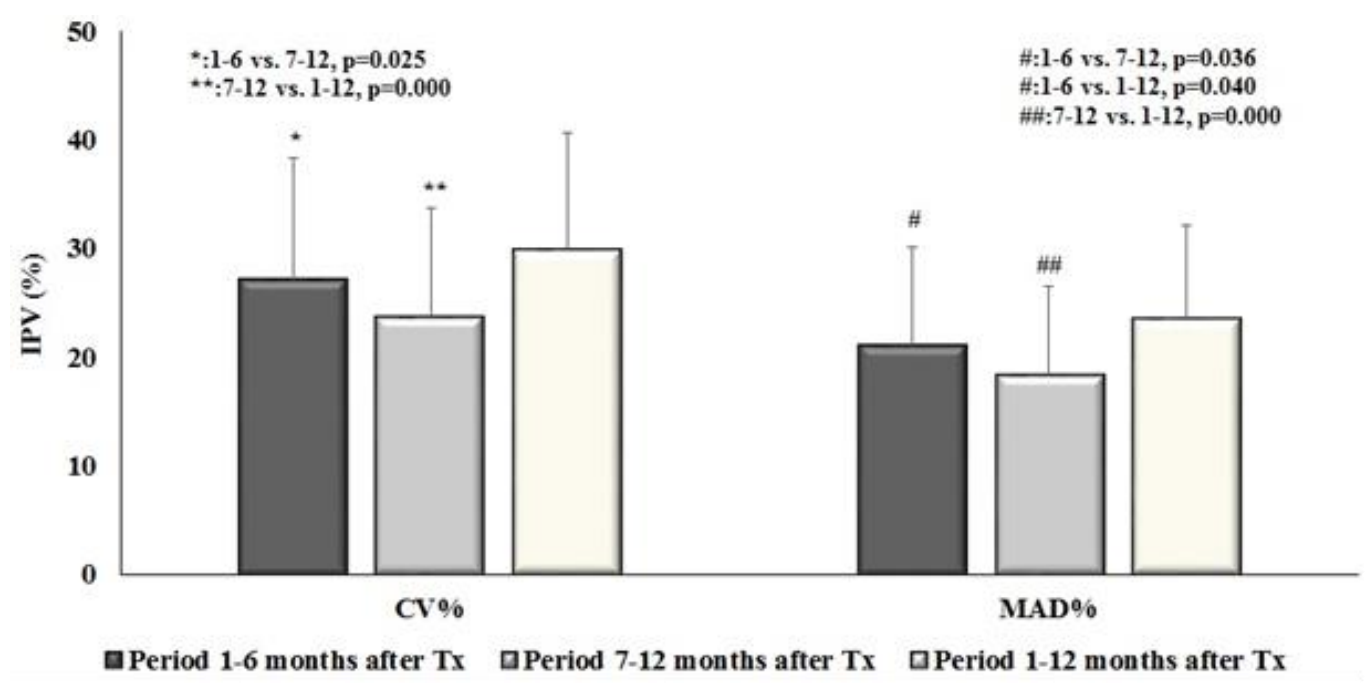

Graph 1. Intrapatient variability in Tac exposure following 12 months after Tx

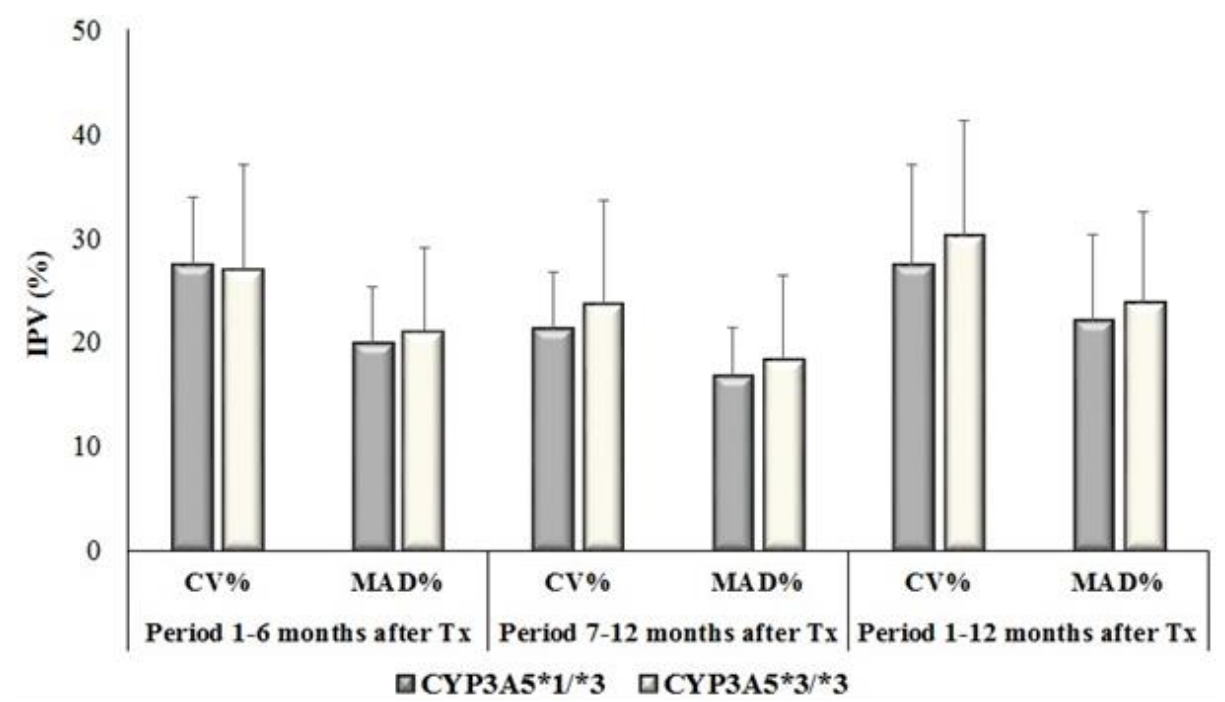

Graph 2. Intrapatient variability in Tac exposure with respect to CYP3A5 genotype 


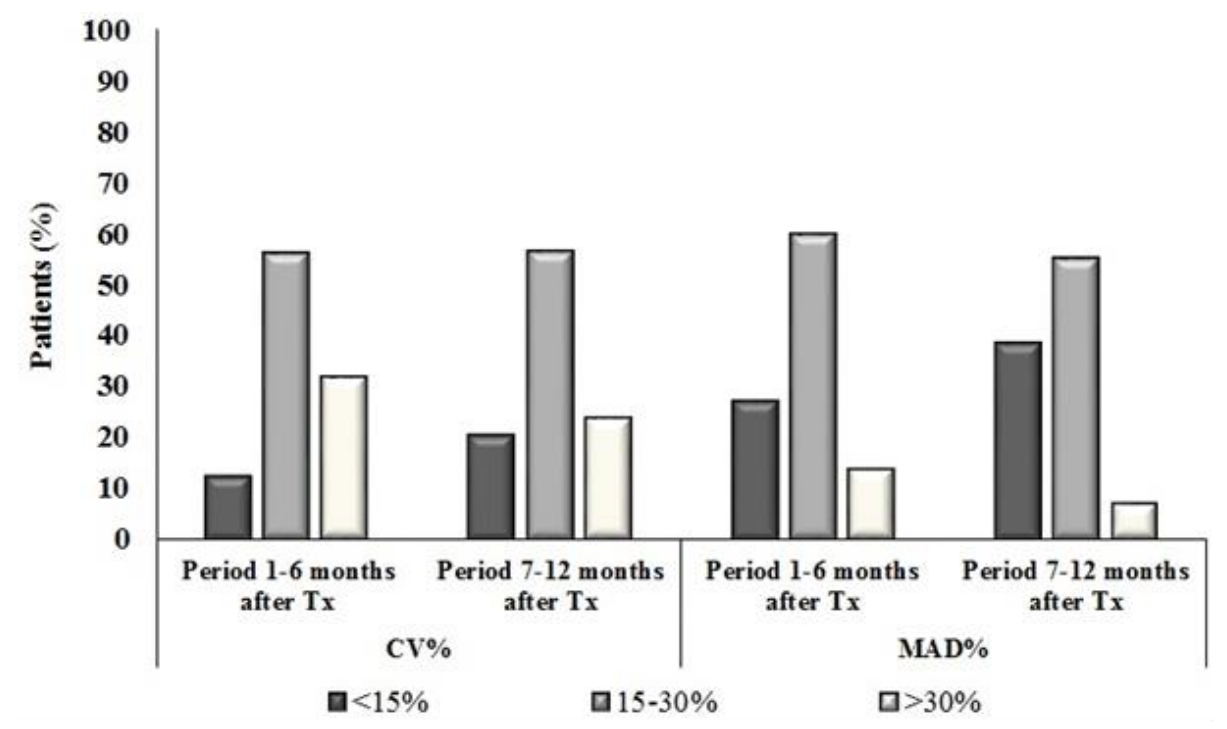

Graph 3. Distribution of Tac IPV among renal transplant recipients

\section{Discussion}

Tacrolimus is considered to be the gold standard in solid organ transplantation, but the narrow therapeutic index, genetic variations and the wide range of inter- and intraindividual pharmacokinetic variability limit its application. Considering this, there is a constant aspiration to identify the factors which contribute to this variability. Cytochrome P450 3A5 gene has 11 different polymorphisms identified to date, but $6986 \mathrm{~A}>\mathrm{G}$ polymorphism was the most extensively studied and indicated as the main determinant of Tac interindividual pharmacokinetic variability. It is characterized by adenine (A) to guanine (G) transition at position 6986 within intron 3 of the CYP3A5 gene and consequently the absence of the active enzyme form (4). The findings of the conducted study reported that the carriers of CYP3A5 $* 1 / * 3$ genotype compared to CYP3A5 *3/*3 carriers required higher Tac daily dose to maintain drug concentration in the optimal range within one year after $T x$ (Table 2). The obtained reuslts were in accordance with the previous studies, which pointed genetic factor as a major predictor of Tac dose requirements (4, $10,11)$. Still, the majority of the previous studies emphasized the role of CYP3A5 polymorphism in the early period after renal transplantation and have been trying to connect this polymorphism with outcomes in the early post-transplant period $(12,13$, 14). This study showed that CYP3A5 polymorphism might have been a significant predictor of Tac exposure in late post-transplant periods (after 6 months), and suggested its consideration as an important contributor of Tac chronic nephrotoxiciy (15). Besides variability in CYP3A5 gene, CYP3A4*22 gene polymorphism is associated with lower CYP3A4 activity and seems to be important determinant of Tac clearance and dose requirements, especially in CYP3A5 non-expressers. Also, gene polymorphisms in ABCB1 98 gene, encoding P-glycoprotein (PGP), have been extensively studied, but results remained inconsistent $(10,16)$. Still, the later research indicated that donor CYP3A5*1 and ABCB1 TT genotype (ABCB1 3435 TT associated with lower PGP activity) may contribute to local Tac transport in transplanted kidney and therefore have a potential role in chronic nephrotoxicity of $\operatorname{Tac}(16,17)$.

In addition to interindividual variability, there is a growing number of clinical studies which support the fact that intraindividual (i.e. intrapatient) variability in Tac exposure correlates with inferior longterm renal transplantation outcomes (9). The previous studies showed a wide range of Tac IPV, with some individuals having a Tac IPV of $<5 \%$, and others having a variability of $>50 \%$, but with an average Tac IPV between 15 and $30 \%$ (2). This is in accordance with the results of our study, which demonstrated that an average IPV was between 20 and $30 \%$. Borra et al. showed that high IPV is closely associated with a composite end point consisting of graft loss, biopsy-proven chronic allograft nephropathy and doubling of plasma creatinine concentration (18). Different factors were assumed to affect Tac IPV, such as concomitant diet, diarrhoeal illnes, drug -drug interactions, genetic factors, substitution of different Tac formulations and non-adherence (2). The present study did not show an association between CV\% or MDA\% and CYP3A5 genotype, which is in accordance with the study of Spierings et al (19). and Pashaee et al. (20). Nearly all authors emphasize non-adherence as one of the dominant causes of Tac IPV, and therefore they suggested that IPV may be considered as an objective measure of adherence to immunosuppresive regimen. Some scientists have reported an improved adherence and decrease of IPV after switching from twice-daily to once-daily Tac formulation (2). Kurnatowska et al. demonstrated that conversion from twice-daily form 
to once-daily form resulted in slightly lower and more stable Tac blood concentration, with a significant decrease in CV of Tac blood levels (44\% versus $22 \%$ ) (21). Additionally, Stifft et al. demonstrated reduced IPV after conversion from twice-daily to once-daily Tac formulation, especially in patients with the CYP3A5*1 allele. In addition, Stifft et al. suggested that decreased variability in Tac exposure is not only a consequence of improved adherence, but also intrinsic pharmacokinetic properties of prolonged-release Tac formulation (22).

Our study showed that $30 \%$ of the patients had high IPV (over 30\%, expressed as CV\%) within the first six months post-transplant and almost $24 \%$ of patients in the other half of the year. Rodrigo et al. used CV\% as a measure of IPV, and demonstrated that more than one third of patients had a blood level CV above 30\% estimated between 4 and 12 month post-transplantation. They showed that acute rejection, re-transplant and CV greater than $30 \%$ were the only variables related to de novo donor-specific antibodies, which can lead to antibodymediated rejection and graft loss (23). Conversely, patients with high TAC IPV, expressed by MAD\%, were less than $15 \%$. Still, most of the studies which showed the association between adverse outcomes and Tac IPV used CV\% as the parameter of IPV. The advantage of the MAD\% over CV\% is that it is less susceptible to outliers, because MAD\% uses the absolute deviations from the mean, whereas CV\% uses the squared deviations from the mean. The further researches should provide the appropriate and mutual parameter of Tac IPV in order to compare different studies and investigate potential determinants of Tac IPV.

Additionally, since renal transplant recipients are not on a stable Tac dose in the early post-transplant period and they often use interacting drugs [such as antibiotics and (pulse) glucocorticoids] in this period, majority of the researchers used only data on Tac exposure measured in the period of 612 months post-transplantation. Therefore, in this particular study, both periods were used to evaluate Tac IPV. Still, almost one quarter of the patients was high variable in period of 7-12 months post-transplant. Shuker et al. emphasize that risk of developing long-term adverse outcomes decreases with time, so patients with high IPV between 6-12 months post-transplant certainly are at a higher risk of adverse outcomes, but this risk is reduced with the time (9).

In conclusion, this study confirms that the CYP3A5 gene polymorphism contributes to the interindividual, but not in intraindividual variability in Tac dose requirements and exposure within the first post -transplant year. Still, renal transplant recipients express high Tac IPV, with one third of the patients in the first and one quarter of the patients in the second half of the first post-transplant year with CV\% above $30 \%$. Conversely, distribution of the patients considering MAD\% as a measure of Tac IPV significantly differed between early and late post-transplant period, but with less highly variable patients. Therefore, appropriate measure of Tac IPV should be established. Further studies should be focused on the factors which may contribute high Tac IPV, such as non-adherence or drug formulation.

\section{Acknowledgments}

This study was supported by grant of Ministry of Science and Technological Development - project number 41018.

Conflict of interest statement None declared. 


\section{References}

1. Staatz CE, Tett SE. Clinical pharmacokinetics and pharmacodynamics of tacrolimus in solid organ transplantation. Clin Pharmacokinet 2004; 43: 623.

[CrossRef][PubMed]

2. Shuker N, van Gelder $T$, Hesselink DA. Intra-patient variability in tacrolimus exposure: causes, consequences for clinical management. Transplant Rev (Orlando) 2015;29: 78-84. [CrossRef][PubMed]

3. Press RR, de Fijter JW, Guchelaar $\mathrm{HJ}$. Individualizing calcineurin inhibitor therapy in renal transplantationcurrent limitations and perspectives. Curr Pharm Des 2010; 16:176-86. [CrossRef][PubMed]

4. Staatz CE, Goodman LK, Tett SE. Effect of CYP3A and $A B C B 1$ single nucleotide polymorphisms on the pharmacokinetics and pharmacodynamics of calcineurin inhibitors: Part I. Clin Pharmacokinet 2010; 49: 14175. [CrossRef][PubMed]

5. Velickovic-Radovanovic R, Mikov M, Catic-Djordjevic A, Stefanovic N, Mitic B, Paunovic G, et al. Genderdependent predictable pharmacokinetic method for tacrolimus exposure monitoring in kidney transplant patients. Eur J Drug Metab Pharmacokinet 2015; 40: 95-102. [CrossRef][PubMed]

6. MacPhee IA. Pharmacogenetic biomarkers: cytochrome P450 3A5. Clin Chim Acta 2012; 413:1312-7. [CrossRef][PubMed]

7. Stefanović N, Cvetković T, Veličković-Radovanović R, Jevtović-Stoimenov T, Stojanović D, Živković N. Significance of CYP3A5 gene polymorphism in Serbian renal transplant patients. Acta Medica Medianae 2013; 52: 33-8. [CrossRef]

8. Stefanović NZ, Cvetković TP, Jevtović-Stoimenov TM, Ignjatović AM, Paunović GJ, Veličković-Radovanović RM. Investigation of CYP $3 A 5$ and $A B C B 1$ gene polymorphisms in the long-term following renal transplantation: Effects on tacrolimus exposure and kidney function. Exp Ther Med 2015; 10: 1149-56. [CrossRef][PubMed]

9. Shuker N, Shuker L, van Rosmalen J, Roodnat JI, Borra LC, Weimar W, et al. A high intrapatient variability in tacrolimus exposure is associated with poor long-term outcome of kidney transplantation. Transpl Int 2016; 29: 1158-67. [CrossRef][PubMed]

10. Hesselink DA, Bouamar $R$, Elens $L$, van Schaik RH, van Gelder $\mathrm{T}$. The role of pharmacogenetics in the disposition of and response to tacrolimus in solid organ transplantation. Clin Pharmacokinet 2014; 53: 12339. [CrossRef][PubMed]

11. Kurzawski M, Dąbrowska J, Dziewanowski K, Domański L, Perużyńska M, Droździk M. CYP3A5 and CYP3A4, but not ABCB1 polymorphisms affect tacrolimus doseadjusted trough concentrations in kidney transplant recipients. Pharmacogenomics 2014 15: 179-88. CrossRef][PubMed]

12. Cusinato DA, Lacchini R, Romao EA, Moysés-Neto M, Coelho EB. Relationship of Cyp3a5 Genotype and Abcb1 Diplotype to Tacrolimus Disposition in Brazilian Kidney Transplant Patients. Br J Clin Pharmacol 2014; 78: 364-72. [CrossRef][PubMed]
13. Han N, Ha S, Yun HY, Kim MG, Min SI, Ha J, et al. Population pharmacokinetic-pharmacogenetic model of tacrolimus in the early period after kidney transplant ation. Basic Clin Pharmacol Toxicol 2014; 114: 400-6. [CrossRef][PubMed]

14. Yaowakulpatana $K$, Vadcharavivad $S$, Ingsathit $A$, Areepium N, Kantachuvesiri S, Phakdeekitcharoen B, et al C. Impact of CYP3A5 polymorphism on trough concentrations and outcomes of tacrolimus minimization during the early period after kidney transplantation. Eur J Clin Pharmacol 2016;72: 277-83. [CrossRef][PubMed]

15. Kuypers DR, Naesens $M$, de Jonge $H$, Lerut $E$, Verbeke $\mathrm{K}$, Vanrenterghem Y. Tacrolimus dose requirements and CYP3A5 genotype and the development of calcineurin inhibitor-associated nephrotoxicity in renal allograft recipients. Ther Drug Monit 2010; 32: 394-404. [CrossRef][PubMed]

16. Kuypers DR. "What do we know about tacrolimus pharmacogenetics in transplant recipients?" Pharmacogenomics 2018; 19: 593-7. [CrossRef][PubMed]

17. Knops N, van den Heuvel LP, Masereeuw R, Bongaers $I$, de Loor $H$, Levtchenko $E$, et al. The functional implications of common genetic variation in CYP3A5 and $A B C B 1$ in human proximal tubule cells. Mol Pharm 2015; 12: 758-68. [CrossRef][PubMed]

18. Borra LC, Roodnat JI, Kal JA, Mathot RA, Weimar W, van Gelder T. High within-patient variability in the clearance of tacrolimus is a risk factor for poor longterm outcome after kidney transplantation. Nephrol Dial Transplant 2010; 25: 2757-63. [CrossRef][PubMed]

19. Spierings N, Holt DW, MacPhee IA. CYP3A5 genotype had no impact on intrapatient variability of tacrolimus clearance in renal transplant recipients. Ther Drug Monit 2013; 35: 328-31. [CrossRef][PubMed]

20. Pashaee N, Bouamar R, Hesselink DA, Roodnat JI, van Schaik RH, Weimar $W$, et al CYP3A5 genotype is not related to the intrapatient variability of tacrolimus clearance. Ther Drug Monit 2011; 33: 369-71. [CrossRef][PubMed]

21. Kurnatowska I, Krawczyk J, Oleksik T, Nowicki M. Tacrolimus dose and blood concentration variability in kidney ransplant recipients undergoing conversion from twice daily to once daily modified release tacrolimus. Transplant Proc 2011; 43: 2954-6. [CrossRef][PubMed]

22. Stifft $F$, Stolk LM, Undre N, van Hooff JP, Christiaans $\mathrm{MH}$. Lower variability in 24-hour exposure during once-daily compared to twice-daily tacrolimus formulation in kidney transplantation. Transplantation 2014; 97: 775-80. [PubMed]

23. Rodrigo E, Segundo DS, Fernández-Fresnedo G, López-Hoyos M, Benito A, Ruiz JC, et al. Within-Patient Variability in Tacrolimus Blood Levels Predicts Kidney Graft Loss and Donor-Specific Antibody Development. Transplantation 2016; 100: 2479-85. [CrossRef][PubMed] 


\title{
INTERINDIVIDUALNA I INTRAINDIVIDUALNA FARMAKOKINETIČKA VARIJABILNOST TAKROLIMUSA TOKOM PRVE GODINE NAKON TRANSPLANTACIJE BUBREGA: EFEKAT CYP3A5 GENSKOG POLIMORFIZMA
}

\author{
Nikola Stefanović ${ }^{1}$, Radmila Veličković-Radovanović1,2, Aleksandra Catić-Đorđević ${ }^{1}$, \\ Ivana Damnjanović ${ }^{1}$, Katarina Dinićs , Branka Mitićc,4, Tatjana Jevtović-Stoimenov ${ }^{5}$, \\ Jelena Bašićs, Milena Despotovićs, Tatjana Cvetkovićz,
}

\author{
${ }^{1}$ Univerzitet u Nišu, Medicinski fakultet, Katedra za farmaciju, Niš, Srbija \\ ${ }^{2}$ Klinika za nefrologiju, Klinički centar Niš, Niš, Srbija \\ ${ }^{3}$ Univerzitet u Nišu, Medicinski fakultet, Niš, Srbija \\ ${ }^{4}$ Univerzitet u Nišu, Medicinski fakultet, Katedra za internu medicinu, Niš, Srbija \\ ${ }^{5}$ Univerzitet u Nišu, Medicinski fakultet, Katedra za biohemiju, Niš, Srbija
}

Kontakt: Nikola Stefanović

Bulevar Dr. Zorana Đinđića 81, 18000 Niš, Srbija

E-mail: nikola.stefanovic@medfak.ni.ac.rs

Cilj ovog istraživanja bila je procena potencijalnog uticaja citohroma P450 3A5 (CYP3A5) 6986A > G genskog polimorfizma na interindividualnu i intraindividualnu varijabilnost (IPV) u izloženosti takrolimusa (Tac) tokom prve godine nakon transplantacije bubrega (Tx). Takođe, mi smo imali za cilj analizu promene u distribuciji bolesnika u pogledu IPV između ranog (<6 meseci) i kasnog perioda ( $>6$ meseci) nakon transplantacije bubrega (Tx). U istraživanje je uključen 91 bolesnik sa transplantiranim bubregom. Ovi bolesnici su bili na Tacbaziranom imunosupresivnom protokolu. Koncentracija korigovana dozom (CO/D) je korišćena kao parametar izloženosti Tac, dok su koeficijent varijacije (CV\%) i srednja apsolutna devijacija (MAD\%) vrednosti CO/D korišćeni kao parametri IPV-a. Transplantirani bolesnici sa CYP3A5*1/*3 genotipom su imali niže vrednosti CO/D u poređenju sa nosiocima CYP3A5*3/*3 genotipa tokom sveukupnog perioda istraživanja $(p<0,01)$. Istraživanje je pokazalo višu IPV u periodu 1-6 meseci u poređenju sa periodom 7-12 meseci nakon Tx, za CV\% i MAD\% ( $p<$ $0,05)$. Rezultati istraživanja su pokazali da nije bilo razlike u IPV u odnosu na CYP3A5 genotip. Razmatrajući CV\%, 32\% i 24\% bolesnika imalo je visoku IPV (iznad 30\%) u prvoj i drugoj polovini prve godine nakon Tx, redom. Analizirajući, MAD\%, 13\% i 7\% bolesnika su imali visoku varijabilnost izloženosti Tac u prvoj i drugoj polovini prve godine, redom. Istraživanje je potvrdilo da CYP3A5 genski polimorfizam doprinosi interindividualnoj, ne intraindividualnoj, varijabilnosti u izloženosti Tac u toku prve godine nakon Tx.

Acta Medica Medianae 2019;58(1):93-101.

Ključne reči: CYP3A5, transplantacija bubrega, takrolimus, interindividualna farmakokinetička varijabilnost, intraindividualna farmakokinetička varijabilnost 